Z. Klin. Chem. Klin. Biochem.

13. Jg. 1975 , S. $143-147$

\title{
Radioimmunoassay of Serum Deoxycorticosterone: Normal Values and Changes of Serum Deoxy- corticosterone after Adrenal Stimulation ${ }^{1}$ )
}

\author{
By M. Schöneshöfer, W. Oelkers and Helga Harendt \\ Division of Endocrinology, Department of Internal Medicine, Klinikum Steglitz, Freie Universität Berlin
}

(Eingegangen am 31. Oktober 1974/25. Februar 1975)

\begin{abstract}
A sensitive radioimmunoassay for estimating serum deoxycorticosterone is described which involves descending "overrunning" paper chromatography. An ethanolic paper eluate is used as a solvent for unlabelled deoxycorticosterone in the preparation of the standard curve. The values of the water blanks $(7 \mathrm{ng} / 1)$ are similar to the sensitivity of the standard curve $(5.8 \mathrm{ng} / \mathrm{l})$. The normal mean serum concentration of deoxycorticosterone was found to be $84 \pm 29 \mathrm{ng} / 1(\mathrm{n}=30)$ in males and $55 \pm 31 \mathrm{ng} / \mathrm{l}(\mathrm{n}=35)$ in females. Serum deoxycorticosterone rose in healthy subjects upon injection of ACTH, after induction of insulin hypoglycemia and after administration of metyrapone, while the rise was absent or blunted in patients with Addison's disease and in patients with pituitary failure.
\end{abstract}

Es wird ein empfindlicher Radioimmunoassay zur Bestimmung von Desoxycorticosteron im menschlichen Serum beschrieben. Eine weitgehende Vortrennung von Desoxycorticosteron wird durch eine absteigende „Durchlauf“-Papierchromatographie erzielt. Als Lösungsmittel für unmarkiertes Desoxycorticosteron zur Erstellung der Standardkurve wird das äthanolische Eluat aus chromatographiertem „Blank“-Papier verwendet. Wasser-,Blanks" (7 ng/l) liegen dadurch in der gleichen Größenordnung wie die Empfindlichkeit der Standardkurve $(5,8 \mathrm{ng} / \mathrm{l})$. Die Normalwerte von Serum-Desoxycorticosteron betragen bei Männern $84 \pm 29 \mathrm{ng} / \mathrm{l}(\mathrm{n}=30)$ und bei Frauen $55 \pm 31 \mathrm{ng} / \mathrm{l}(\mathrm{n}=35)$. Bei Gesunden steigt die Serum-Desoxycorticosteron-Konzentration nach Injektion von ACTH und Insulin, sowie nach oraler Gabe von Metopiron an, während der Anstieg bei Addison-Patienten und bei Patienten mit Hypophyseninsuffizienz ausbleibt, bzw. stark abgeschwächt ist.

11-Deoxycorticosterone causes hypertension in patients with 11-hydroxylase deficiency $(1,2)$ and it may play a role in the pathogenesis of "low renin hypertension" (3-5). An adequate study of these diseases necessitates a sensitive assay of deoxycorticosterone in man. Several methods for estimating secretion, excretion and plasma concentration of deoxycorticosterone have been developed in the last ten years. These methods are based on double isotope dilution $(6,9)$, competitive protein binding (7), gas liquid chromatography (8) and radioimmunoassay technique (9-11). Mean plasma deoxycorticosterone concentrations in normal subjects reported hitherto in the literature exhibit a considerable variability (range: $50-260 \mathrm{ng} / \mathrm{l}$ ) which is obviously due to limited specificity and various blank problems. We describe in this paper a sensitive radioimmunoassay of serum deoxycorticosterone concentration involving "overrunning" paper chromatography, and in which blank paper eluate serves as a solvent for unlabelled standard deoxycorticosterone. Normal values in males and females and changes of serum deoxycorticosterone levels after adrenal stimulation are reported.

\footnotetext{
$\left.{ }^{1}\right)$ Supported by Deutsche Forschungsgemeinschaft
}

\section{Materials and Methods}

Solvents and reagents

Analytical grade chemicals were used throughout. Deoxycorticosterone (21-hydroxy-4-pregnene-3.20-dione) was obtained from E. Merck (Darmstadt). Dilutions of deoxycorticosterone for the radioimmunoassay standard curve were set up monthly. $\left[1.2-{ }^{3} \mathrm{H}\right]$-deoxycorticosterone $(50 \mathrm{Ci} / \mathrm{mmole})$ was purchased from New England Nuclear Company and purified by paper chromatography fortnightly.

The anti-serum from rabbits immunized by injection of deoxycorticosterone-3-carboxy-methoxime was kindly provided by Dr. $R$. Fraser, MRC Blood Pressure Unit, Glasgow.

Borate buffer (pH 8 ) containing $2 \%$ ethanol and $0.1 \%$ lysozyme (E. Merck, Darmstadt) was used for incubation.

Tritium was measured in a liquid-scintillation spectrometer (Packard Instruments, model 3385).

Pipettes and counting vials were of the disposable type. Conical extraction tubes were washed with dilute detergent for several hours and thoroughly rinsed with distilled water followed by three washings with dichloromethane. Immediately before use they were rewashed twice with dichloromethane. Whatman-2paper strips $(1.8 \times 45 \mathrm{~cm})$ to be used for chromatography were extracted with ethanol for 24 hours in a Soxleth apparatus. Immediately before use, the strips were extracted chromatographically with ethanol for about 4 hours.

Extraction and chromatography

Serum samples $(0.5-3 \mathrm{ml})$ to which ${ }^{3} \mathrm{H}$-deoxycorticosterone $(0.018 \mu \mathrm{Ci})$ had been added, were extracted with $9 \mathrm{ml}$ carbon 
tetrachloride in conical glass tubes. The extracts were evaporated to dryness under a stream of nitrogen at $40^{\circ} \mathrm{C}$. The residues were redissolved in $150 \mu$ lof dichloromethane and chromatographed in the system $n$-hexane/methanol/water $(10+8+2$ by vol). After 20 hours, deoxycorticosterone had moved about $12 \mathrm{~cm}$. ${ }^{3} \mathrm{H}$-deoxycorticosterone was located on paper strips by radio-scanning (Packard Instruments, model 7200). ${ }^{3} \mathrm{H}$-deoxycorticosterone was eluted from the paper with $2 \mathrm{ml}$ of ethanol.

\section{Radioimmunoassay}

From these eluates, duplicate aliquots of $500 \mu \mathrm{l}$ were pipetted into $1.6 \mathrm{ml}$ plastic tubes for radioimmunoassay, and a further $500 \mu \mathrm{l}$ aliquot was pipetted into a counting vial for estimating ${ }^{3} \mathrm{H}$-recovery. Where necessary, the counts in the radioimmunoassay aliquots were adjusted to standard curve ${ }^{3} \mathrm{H}$-level by adding appropriate ${ }^{3} \mathrm{H}$-deoxycorticosterone quantities.

Standard curves were set up in duplicate. Unlabelled deoxycorticosterone ( $800 \mathrm{pg}$ to $6.24 \mathrm{pg}$ in doubling dilution steps) was dissolved in $500 \mu \mathrm{l}$ of an ethanolic paper blank eluate. $0.003 \mu \mathrm{Ci}$ of ${ }^{3} \mathrm{H}$-deoxycorticosterone in $\mathbf{1 0 0} \mu \mathrm{l}$ ethanol was added for each standard tube.

Both unknown and standard curve samples were evaporated to dryness under a stream of nitrogen at $40^{\circ} \mathrm{C}$. $0.5 \mathrm{ml}$ of antiserum, diluted $1: 12000$ with borate-lysozyme-buffer, was added and mixed for $30 \mathrm{~min}$ on a rotatory mixer at room temperature. After incubation at $4{ }^{\circ} \mathrm{C}$ for 16 hours, separation of free and bound deoxycorticosterone was achieved using the dextran-coated charcoal method (12). After centrifugation, the supernatant was transferred into counting vials using a semiautomatic decanting apparatus (according to P. Vecsei, Heidelberg) which allows simultaneous decanting of 150 tubes. The percentage of activity in the supernatant represents the hormone fraction bound to the antibody.

Evaluation of the radioimmunoassay data and plotting of standard curves were done with a modular constructed computer program (13). An IBM-1800 computer was used for the operating procedures. Results presented in this paper were obtained by evaluation according to a logarithmic interpolation model.

\section{Results}

Physicochemical constants of the ${ }^{3} \mathrm{H}$-deoxycorticosterone-antibody reaction

The equilibrium constant for the deoxycorticosteroneantibody reaction determined by Scatchard plot is $3 \cdot 10^{9} \mathrm{l} / \mathrm{mol}$ at $4^{\circ} \mathrm{C}$. The rate of dissociation of the ${ }^{3} \mathrm{H}$-labelled deoxycorticosterone-antibody complex at $4{ }^{\circ} \mathrm{C}$ was determined by preincubation for two hours at $4{ }^{\circ} \mathrm{C}$ followed by the addition of $2000 \mathrm{pg}$ of unlabelled deoxycorticosterone; ${ }^{3} \mathrm{H}$-measurement of the supernatant in 1 hour steps up to 7 hours then permitted the estimation of the dissociation rate of bound ${ }^{3} \mathrm{H}$ deoxycorticosterone. The semilogarithmic plot of the results yielded a straight line indicating a first order reaction. Half-life time of dissociation was 3.8 hours. The dissociation constant was calculated to be $5 \cdot 10^{-5}$ $\mathrm{s}^{-1}$ and the association constant $1,5 \cdot 10^{5} \mathrm{l} / \mathrm{mol} \cdot \mathrm{s}$.

\section{Standard curve parameters}

Figure 1 shows a semilogarithmic computer plot of a representative standard curve including the $95 \%$ confidence range (13). The mean sensitivity of standard

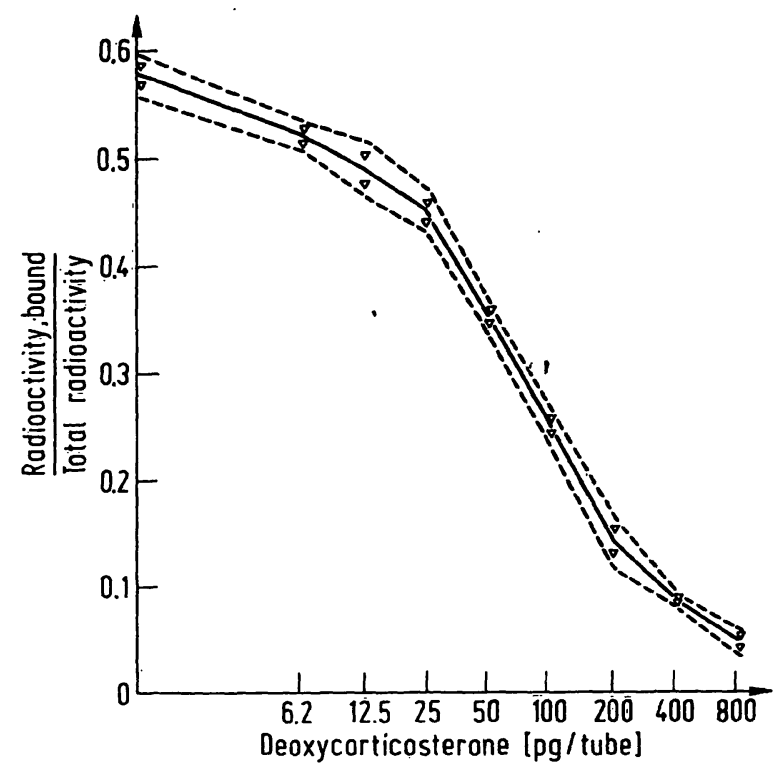

Fig. 1. A representative semilogarithmic standard curve of deoxycorticosterone radioimmunoassay. Broken lines indicate the $95 \%$ confidencel range (13).

curves ( 2 standard deviations of the zero point) was $3.5 \pm 2.8$ (S.D.) pg of deoxycorticosterone. This corresponds to $5.8 \pm 4.64$ (S.D.) $\mathrm{ng} / \mathrm{l}$ for the deoxycorticosterone assay when $3 \mathrm{ml}$ of serum were used.

As a further measure of sensitivity of the standard curve we determined the amount of unlabelled deoxycorticosterone which displaced $50 \%$ of the labelled hormone from the antibody. The mean sensitivity calculated from 34 standard curves was $71 \pm 12$ (S.D.) pg corresponding to $118 \pm 19.9$ (S.D.) $\mathrm{ng} / 1$ for a $3 \mathrm{ml}$ serum sample.

\section{Assay parameters}

The ultimate specificity of the assay was achieved by the applied "overrunning" chromatographic system which provides a high degree of separation of deoxycorticosterone from the other major $\mathrm{C}_{21}$-steroids. Monohydroxylated progesterone derivates exhibit a chromatographic behaviour similar to that of deoxycorticosterone but only $17 \alpha$-hydroxy-progesterone $\left(R_{D O C}=0.68\right)$ arises in appreciable amounts in human serum (16). The cross reaction of $17 \alpha$-hydroxy-progesterone with the deoxycorticosterone-antibody was found to be less than $0.01 \%$.

Recovery of ${ }^{3} \mathrm{H}$-labelled deoxycorticosterone added to serum averaged $53.5 \pm 6.1 \%(n=35)$ after chromatography.

Distilled water was used for blank studies. The mean value of $3 \mathrm{ml}$ water blanks which were run in 21 different assays was $7 \pm 11.3 \mathrm{ng} / 1$. It must be stressed that sometimes slightly negative values were obtained. Such values were necessarily considered as zeros in the calculation of mean. Therefore, the indicated mean value of water blanks is overestimated. The mean blank of 
the chromatographic paper determined by a standard curve with pure ethanol as solvent for unlabelled deoxycorticosterone was $13.5 \pm 5.8$ (S.D) pg/tube corresponding to $22.4 \pm 9.6$ (S.D.) $\mathrm{ng} / \mathrm{l}$ for a $3 \mathrm{ml}$ serum sample. As a consequence of these blank studies, we used paper eluate as the solvent for standard deoxycorticosterone in the final method.

Accuracy of the deoxycorticosterone radioimmunoassay was studied by adding various amounts of unlabelled deoxycorticosterone to distilled water or serum with known deoxycorticosterone concentration. The results are shown in Table 1.

Intraassay and interassay variability of deoxycorticosterone measurements in sera with different deoxycorticosterone concentrations is shown in Table 2. Both exhibit the well-known inverse relationship between concentration and relative error.

Different amounts of pooled serum $(0.5,1,1.5,2,2.5$ and $3 \mathrm{ml}$ ) were assayed in order to study the influence of serum volume on assay accuracy. Samples containing less than $3 \mathrm{ml}$ were made up to $3 \mathrm{ml}$ with distilled water. The relationship between estimated deoxycorticosterone and original serum volume is shown in Figure 2. The coefficient of correlation $(r=0.993)$ indicates the absence of a systematic error introduced by variations in serum volume.

\section{Normal values}

Serum deoxycorticosterone concentration was measured in 65 healthy subjects ( 30 males and 35 females).

Tab. 1. Accuracy of deoxy corticosterone assay in $3 \mathrm{ml}$ water or serum. Mean values derived from $\mathrm{N}$ different assays.

\begin{tabular}{lrll}
\hline $\begin{array}{l}\text { Deoxycorti- } \\
\text { costerone } \\
\text { added (ng/l) }\end{array}$ & N & \multicolumn{2}{l}{ Mean Recovered \pm S.D. (\%) } \\
\hline 66 & 18 & Water & Serum \\
100 & 8 & $109.5 \pm 31.1$ & \\
264 & 17 & $102.8 \pm 22.0$ & \\
400 & 7 & & $102.2 \pm 16.2$ \\
528 & 17 & $105.2 \pm 17.8$ & \\
\hline
\end{tabular}

Tab. 2. Intraassay and interassay variation of serum deoxycorticosterone radioimmunoassay.

\begin{tabular}{|c|c|c|c|c|c|}
\hline \multicolumn{3}{|c|}{ Intra-Assay Variation } & \multicolumn{3}{|c|}{ Inter-Assay Variation } \\
\hline $\begin{array}{l}\text { Mean } \\
\text { Serum } \\
\text { Concen- } \\
\text { tration } \\
\text { (ng/l) }\end{array}$ & $\mathbf{N}$ & $\begin{array}{l}\text { Coeffi- } \\
\text { cient } \\
\text { of Vari- } \\
\text { ation } \\
(\%)\end{array}$ & $\begin{array}{l}\text { Mean } \\
\text { Serum } \\
\text { Concen- } \\
\text { tration } \\
\text { (ng/l) }\end{array}$ & $\mathbf{N}$ & $\begin{array}{l}\text { Coeffi- } \\
\text { cient } \\
\text { of Vari- } \\
\text { ation } \\
(\%)\end{array}$ \\
\hline $\begin{array}{r}47 \\
211 \\
653\end{array}$ & $\begin{array}{l}11 \\
12 \\
11\end{array}$ & $\begin{array}{c}14.2 \\
8.7 \\
6.9\end{array}$ & $\begin{array}{r}66 \\
214 \\
502\end{array}$ & $\begin{array}{r}11 \\
8 \\
7\end{array}$ & $\begin{array}{r}21.7 \\
13.4 \\
7.8\end{array}$ \\
\hline
\end{tabular}

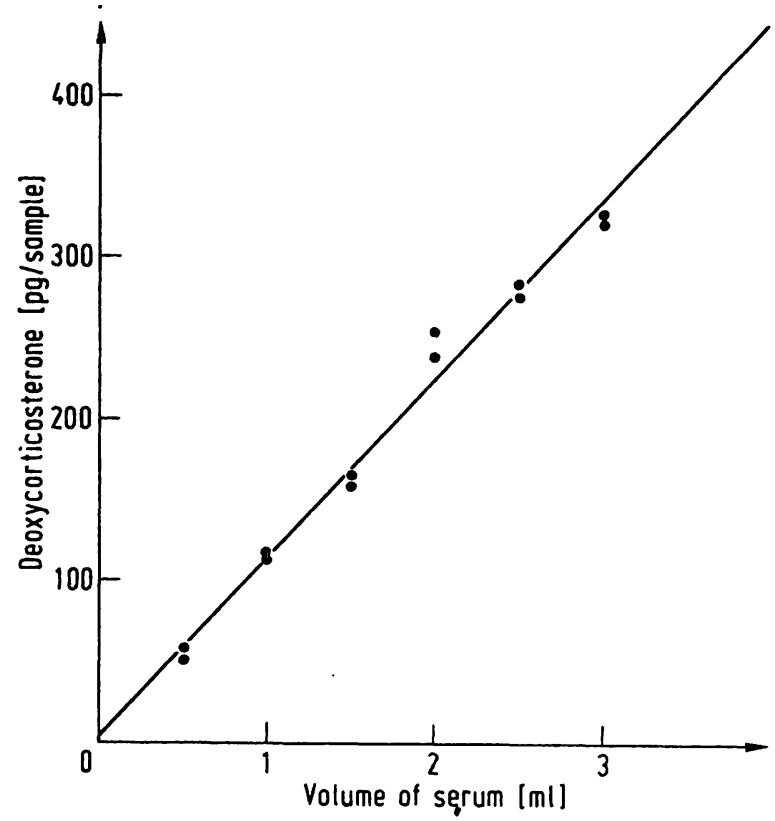

Fig. 2. Correlation of serum deoxycorticosterone assayed and original serum volume $(n=12)$. Equation of regression: $\mathrm{Y}=3.73+110.5 \mathrm{X}$; coefficient of correlation $=0.993$.

Venous blood was taken between 8 a.m. and 2 p.m.. Mean deoxycorticosterone concentration in males and females was $84 \pm 29$ (S.D.) $\mathrm{ng} / 1$ (range $34-142 \mathrm{ng} / \mathrm{l}$ ) and $55 \pm 31$ (S.D.) $\mathrm{ng} / 1$ (range $18-121 \mathrm{ng} / \mathrm{l}$ ) respectively. The difference between mean male and female serum deoxycorticosterone levels was statistically significant $(p<$ 0.001 using t-test and $p<0.002$ using Wilcoxon-test). It must be pointed out that no attention was drawn to possible changes of deoxycorticosterone levels during the menstrual cycle in women, or to circadian variability.

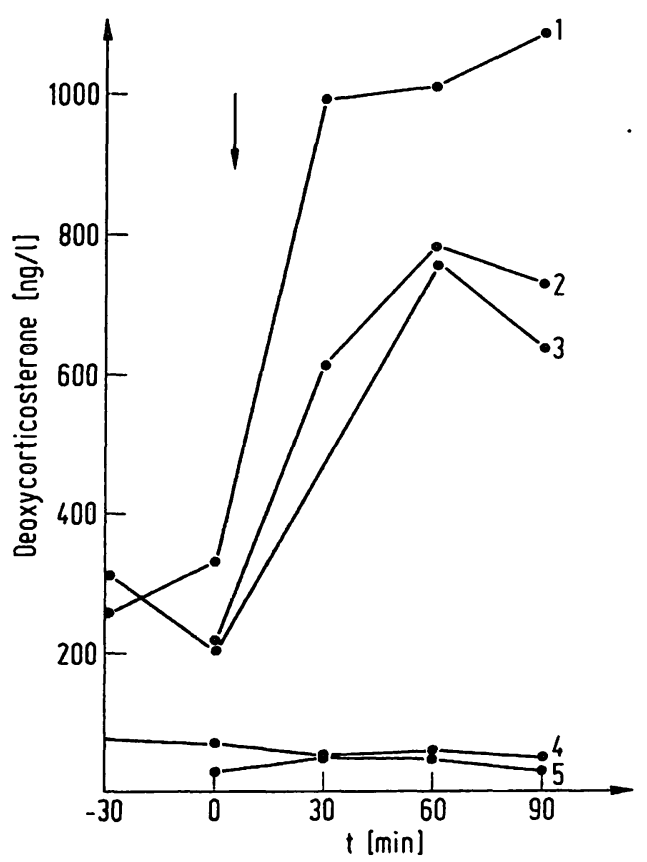

Fig. 3. Changes in serum deoxycorticosterone concentration after i.v. injection (arrow) of $250 \mu \mathrm{g} \mathrm{ACTH}$ between 8 a.m. and 9 a.m., 1-3: Normal subjects; 4 and 5: Patients with Addison's diseasc. 
Changes of serum deoxycorticosterone after adrenal stimulation

Several authors have demonstrated a rise of plasma deoxycorticosterone concentration after injection of $\operatorname{ACTH}(6,7,9)$. Figure 3 shows a marked increase of serum deoxycorticosterone in 3 healthy subjects after i.v. injection of $0.25 \mathrm{mg}$ of ACTH, while no response occurred in 2 patients with Addison's disease.

Figure 4 shows the effect of insulin induced hypoglycemia on serum deoxycorticosterone. It increased markedly in 3 healthy subjects, but failed to rise in 2 patients with pituitary insufficiency. 8 hours after administration of metyrapone $(30 \mathrm{mg} / \mathrm{kg}$ body weight

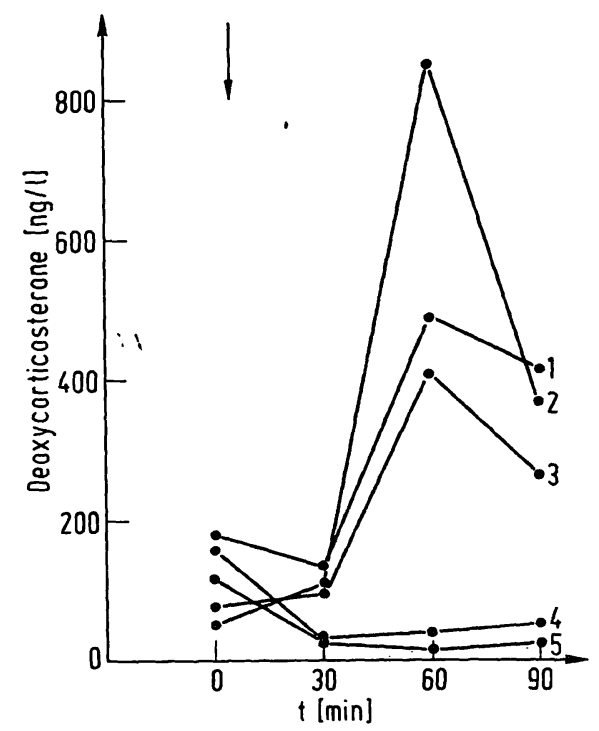

Fig. 4. Changes in serum deoxycorticosterone concentration after i.v. injection (arrow) of $0.1 \mathrm{IE} / \mathrm{kg}$ body weight of insulin between 8 a.m. and 9 a.m. 1-3: Normal subjects; 4 and 5: Acromegalic patients after radiotherapy.

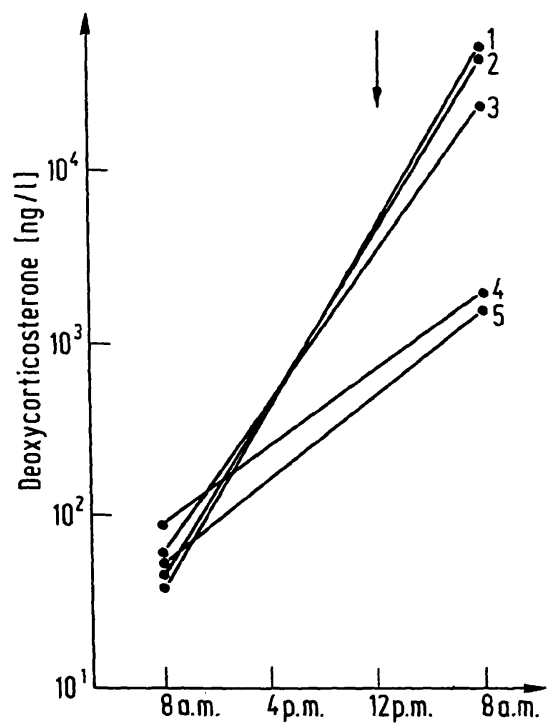

Fig. 5. Serum deoxycorticosterone concentration before ( 8 a.m.) and 8 hours after oral administration of $30 \mathrm{mg} / \mathrm{kg}$ of metyrapone (arrow). 1-3: Healthy subjects; 4 and 5: Acromegalic patients after radiotherapy. at midnight) a very large increment of serum deoxycorticosterone was observed in $\mathbf{3}$ healthy subjects, while the response to metyrapone in 2 patients with pituitary insufficiency was blunted (Fig. 5).

\section{Discussion}

Estimation of the very small quantities of deoxycorticosterone present in serum relative to other structurally related C-21 corticosteroids presents a considerable analy tical challenge. Up to date there is no question that radioimmunoassay is the most convenient technique to solve this problem adequately. However, in spite of the generally good specificity of antibodies raised against deoxycorticosterone, preliminary chromatographical purification is necessary before the radioimmunoassay procedure (9-11). From the more intensively studied radioimmunoassays of plasma aldosterone (14) it is known that the chromatographic step is prone to produce considerable blank values which limit the sensitivity of the assay in practice. In the present method the mean paper blank of $13.5 \mathrm{pg}$ (corresponding to $22.5 \mathrm{ng} / \mathrm{l}$ ) is eliminated by setting up the standard curve in ethanolic eluates of chromatographed paper blanks. Thereby, the blanks arising from distilled water samples $(7 \mathrm{ng} / \mathrm{l})$ approach the theoretical sensitivity of the standard curve $(5.8 \mathrm{ng} / 1)$ indicating that blanks are almost quantitatively eliminated.

The normal values measured by the present method are within the lower range of values determined by other authors (Tab. 3). However, the significant difference of mean female $(55 \mathrm{ng} / \mathrm{l})$ and male $(84 \mathrm{ng} / \mathrm{l})$ deoxycorticosterone serum concentration has not yet been reported. Similar sex differences in the concentration of another monohydroxylated progesterone derivate $-17 \mathrm{OH}$-progesterone - were recently described by Youssefnejadian et al. (16). Although partially formed

Tab. 3. Comparison of mean plasma or serum deoxy corticosterone in normal subjects determined by different methods and authors.

$\mathrm{P}=$ plasma; $\mathrm{S}=$ serum. DID: Double isotope dilution; GLC: Gas-liquid chromatography; CPBA: Competitive protein binding assay; RIA: radioimmunoassay; SR/Cl: Calculated from secretion rate and metabolic clearance rate.

\begin{tabular}{|c|c|c|c|c|}
\hline Reference & Method & $\mathbf{N}$ & $\begin{array}{l}\text { Mean } \\
\text { (ng/l) }\end{array}$ & $\begin{array}{l}\text { Range } \\
\text { (ng/1) }\end{array}$ \\
\hline Arnold (9) & DID & 24 & $70(\mathrm{P})$ & $40-180$ \\
\hline Arnold (9) & RIA & 10 & $50(\mathrm{P})$ & $10-120$ \\
\hline Wilson (8) & GLC & 20 & $98(P)$ & $41-172$ \\
\hline Brown (7) & CPBA & 24 & $50(P)$ & $50-100$ \\
\hline $\begin{array}{l}\text { Schambelan } \\
\text { (15) }\end{array}$ & $\begin{array}{l}\text { SR/Cl } \\
\text { GLC }\end{array}$ & 3 & $260(P)$ & \\
\hline Castro (11) & RIA & 24 & $64(P)$ & $28-170$ \\
\hline Mantero (5) & RIA & & $139(\mathrm{P})$ & \\
\hline present method & RIA & $\begin{array}{l}35 \% \\
300\end{array}$ & $\begin{array}{l}55(\mathrm{~S}) \\
84\end{array}$ & $\begin{array}{l}18-121 \\
34-141\end{array}$ \\
\hline
\end{tabular}


in the ovaries, the mean plasma concentration in females during the follicular phase $(400=150 \mathrm{ng} / \mathrm{l})$ was significantly lower than in males $(1230 \pm 650 \mathrm{ng} / \mathrm{l})$. Only in the luteal phase did the mean plasma concentrations in females $(1340 \pm 570 \mathrm{ng} / \mathrm{l})$ reach the normal level in males. However, plasma corticosterone levels were found to be higher in females $(6550 \pm 2710 \mathrm{ng} / \mathrm{l})$ than in males $(3960 \pm 2280 \mathrm{ng} / \mathrm{l})(17)$. In the latter study the higher values in females were explained by a larger response to endogenous ACTH compared with males. Our results are not consistent with these findings. At present, these

\section{References}

1. Biglieri, E. G., Herron, M. A. \& Brust, N. (1966), J. Clin. Invest. 45, 1946-1954.

2. Goldsmith, O., Solomon, D. H. \& Horton, R. (1967), N. Engl. J. Med. 277, 673-677.

3. Brown, J. J., Fraser, R., Love, D. R., Ferris, J. B., Lever, A. F. \& Robertson, J. I. S. (1972), Lancet II, 243-247.

4. Genard, P., Palem-Vliers, M. \& Sullon, J. (1973), In The Sixth Meeting of the International Study Group for Steroid Hormones, p. 36, Rome.

5. Mantero, F., Sonino, N., Armanini, D. \& Boscaro, M. (1973), In The Sixth Meeting of the International Study Group for Steroid Hormones, p. 68, Rome.

6. Oddie, C. J., Coghlan, J. P. \& Scoggins, B. S. (1972), J. Clin. Endocrinol. Metab. 34, 1039-1054.

7. Brown, R. D. \& Strott, C. A. (1971), J. Clin. Endocrinol. Metab. 32, 744-750.

8. Wilson, A. \& Fraser, R. (1971), J. Endocrinol. 51, 557-567.

9. Arnold, M. L. \& James, V. H. T. (1971), Steroids 18, 789800. discrepancies cannot be explained and further studies on possible cyclic changes of serum deoxycorticosterone in females and of episodic deoxycorticosterone secretion in both sexes, are needed.

\section{Acknowledgements}

We arc indebted to Dr. R. Fraser, MRC Blood Pressure Unit, Glasgow for generously supplying the deoxycorticosteroneantibody and to Dr. P. Koeppe, Klinikum Steglitz, for providing computer facilities in the department of radiology and nuclear medicine.
10. Fraser, R., Wilson, A. \& Holmes, E. (1973), Acta Endocrinol. (Copenhagen), Suppl. 177, 37.

11. Castro, A., Bartos, D., Jelen, B. \& Kutas, M. (1973), Steroids $22,851-867$.

12. Herbert, V., Lau, L. S., Gottlieb, C. W. \& Bleicher, S. J. (1965), J. Clin. Endocrinol. Metab. 25, 1375-1383.

13. Schöneshöfer, M. (1975), Acta Endocrinol. (Copenhagen), Suppl. 193, 116.

14. Mayes, D., Furuyama, S., Kem, D. C. \& Nugent, C. A. (1970), J. Clin. Endocrinol. Metab. 30, 682-685.

15. Schambelan, M. \& Biglieri, E. G. (1972), J. Clin. Endocrinol. Metab. 34, 695-702.

16. Youssefnejadian, E., Florensa, E., Collins, W. P. \& Sommerville, I. F. (1972), Steroids 20, 773-788.

17. Nabors, C. J., West, C. D., Mahajan, D. K. \& Tyler, F. H. (1974), Steroids 23, 363-378.

Dr. M. Schöneshöfer

Klinikum Steglitz

Medizinische Klinik und Poliklinik

Abteilung Endokrinologie

1 Berlin 45

Hindenburgdamm 30 


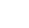

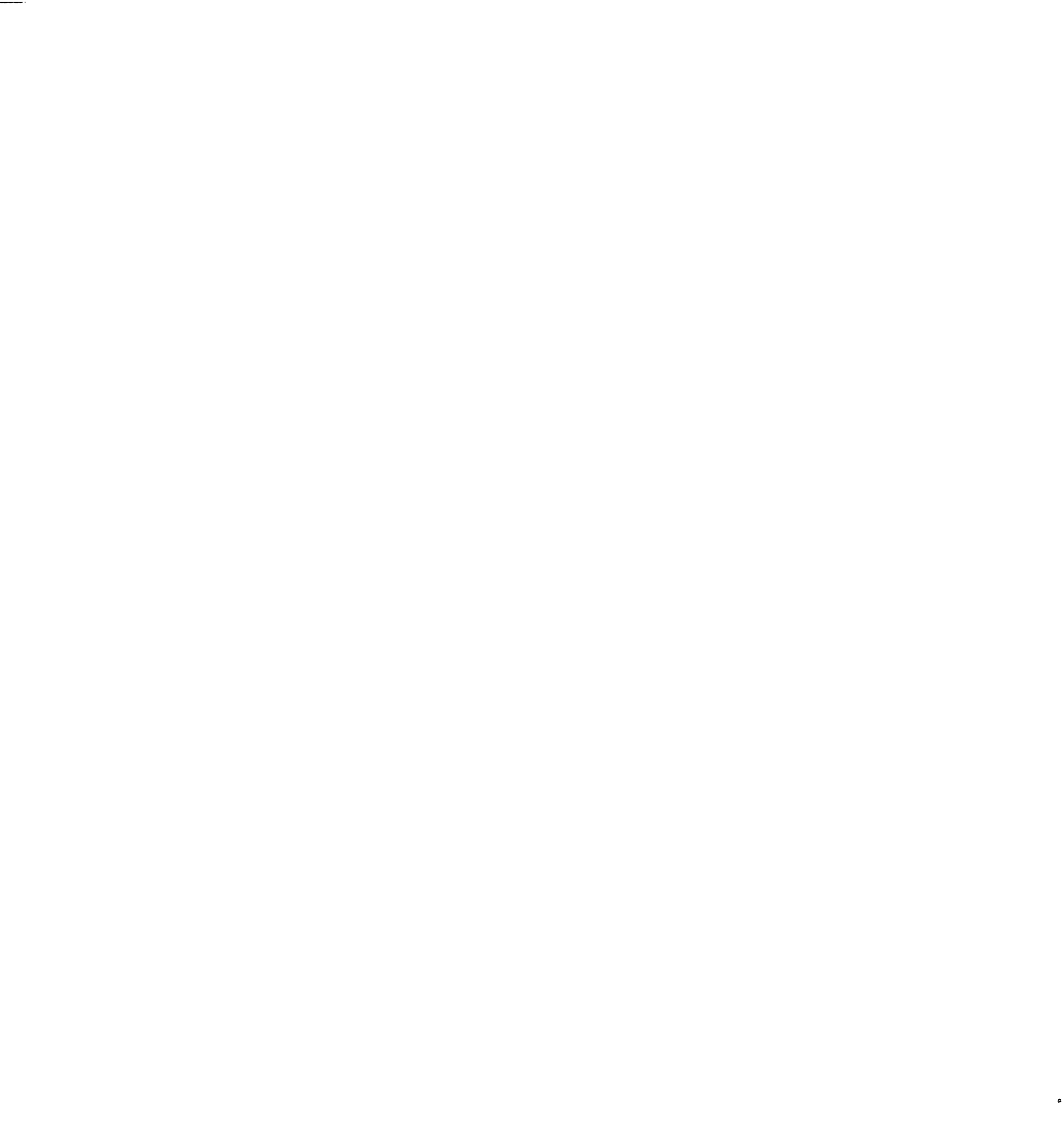

